\title{
Attenuation of nicotine-evoked $\mathrm{Ca}^{2+}$ influx by antibody to the nicotinic acetylcholine receptor $\alpha 3$ subunits in human embryonic kidney cells
}

\author{
Shota Kobayashi' ${ }^{1,2}$, Shigeru Yokoyama ${ }^{3}$, Takahiro Maruta ${ }^{4}$, Akiko Muroyama ${ }^{1}$, Hiroaki Yoshikawa ${ }^{2,5}$, \\ Yasuhide Mitsumoto ${ }^{1^{*}}$ \\ ${ }^{1}$ Laboratory of Alternative Medicine and Experimental Therapeutics, Department of Clinical Pharmacy, Faculty of Pharmaceutical \\ Sciences, Hokuriku University, Kanazawa, Japan \\ ${ }^{2}$ Health Service Center, Kanazawa University, Kanazawa, Japan \\ ${ }^{3}$ Department of Biophysical Genetics, Kanazawa University Graduate School of Medicine, Kanazawa, Japan \\ ${ }^{4}$ Neurological Center, Kanazawa Nishi Hospital, Kanazawa, Japan \\ ${ }^{5}$ Department of Neurology and Neurobiology of Aging, Kanazawa University Graduate School of Medical Science, Kanazawa, \\ Japan \\ Email: ${ }^{*}$ y-mitsumoto@hokuriku-u.ac.jp
}

Received 19 April 2013; revised 20 May 2013; accepted 28 May 2013

Copyright (C) 2013 Shota Kobayashi et al. This is an open access article distributed under the Creative Commons Attribution License, which permits unrestricted use, distribution, and reproduction in any medium, provided the original work is properly cited.

\begin{abstract}
Autoantibody against neuronal nicotinic acetylcholine receptor (nAChR) $\alpha 3$ subunit is implicated in severe autonomic dysfunction in the patients with autoimmune autonomic ganglionopathy (AAG). Although this autoantibody has been revealed to impair fast excitatory synaptic transmission in autonomic ganglia, its precise mechanism remains unknown. Here, we show that antibody-induced reduction of cell-surface $\alpha 3$ subunits result in impairment of nicotine-evoked $\mathrm{Ca}^{2+}$ influx in stably transfected human embryonic kidney cells. These effects of the antibody were remarkably inhibited by interfering with the endocytic machinery at low-temperature. We conclude that reduction of $\mathrm{nAChR}$ in autonomic ganglia can be mediated by the endocytosis of $\alpha 3$ subunits, and resulted in autonomic failure in AAG patients.
\end{abstract}

Keywords: Nicotinic Acetylcholine Receptor $\alpha 3$ Subunit; Antibody; Endocytosis; $\mathrm{Ca}^{2+}$ Influx;

Autoimmune Autonomic Ganglionopathy

\section{INTRODUCTION}

Autoimmune autonomic ganglionopathy (AAG) is an acquired immune-mediated disorder characterized by severe autonomic dysfunction. The clinical manifestations of AAG include orthostatic hypotension, gastroin-

"Corresponding author. testinal hypomotility, urinary retention and sudomotor dysfunction [1]. About $50 \%$ of patients with AAG have autoantibodies against ganglion-type neuronal nicotinic acetylcholine receptor (ganglionic nAChR) [2]. The $\mathrm{nAChR}$ is a pentameric ligand-gated cation channel. In autonomic ganglia, nAChR containing $\alpha 3$ and $\beta 4$ subunits mainly mediates fast excitatory synaptic transmission $[3,4]$.

Previous electrophysiological studies have revealed pathogenic roles of anti- $\alpha 3$ subunit autoantibody. Autonomic dysfunction was induced in rabbits immunized with recombinant $\alpha 3$ subunit protein [5] and in mice given anti- $\alpha 3$ subunit antibodies [6]. Vernino et al. [7] demonstrated that IgG from the seropositive patients specifically reduced ganglionic $\mathrm{nAChR}$ current in human embryonic kidney (HEK) cells. In this study, we further examined whether antibody-induced reduction in the protein levels of cell-surface $\alpha 3$ subunits could cause ganglionic nAChR dysfunction in HEK293 cells.

\section{MATERIALS AND METHODS}

\subsection{Cell Culture}

HEK293 cells stably co-expressing $\alpha 3$ and $\beta 4$ subunits (HEK293- $\alpha 3 \beta 4$ cells) or mock-transfected HEK293 cells were established in our laboratory [8] and cultured in a humidified incubator with $5 \% \mathrm{CO}_{2}$ at $37^{\circ} \mathrm{C}$ in Dulbecco's modified Eagle's medium containing 10\% fetal bovine serum and $100 \mu \mathrm{g} / \mathrm{ml} \mathrm{G} 418$ (Roche Applied Science, Germany). 


\subsection{Subcellular Fractionation}

The cells on culture dishes were scraped, pelleted by centrifugation, and homogenized in a solution containing $0.32 \mathrm{M}$ sucrose, $2 \mathrm{mM}$ EDTA, $2 \mathrm{mM}$ EGTA, $20 \mathrm{mM}$ HEPES and protease inhibitor cocktail (BioVision Research Products, USA) at pH 7.2. Subcellular fractionation was performed as summarized in Figure 1(a). At first, we centrifuged out the nuclear pellet (P1 fraction) at $1000 \times \mathrm{g}$ for $5 \mathrm{~min}$. The resulting supernatant was then centrifuged at $170,000 \times \mathrm{g}$ for $60 \mathrm{~min}$, and cytosolic supernatant was transferred to a new tube (S2 fraction). The resulting pellet of membrane fraction was resuspended in the homogenization solution (P2 fraction). Protein concentration of each fraction was determined using DC protein assay (BIO-RAD, USA).

\subsection{Immunoblot Analysis}

Each subcellular fraction (10 $\mu \mathrm{g}$ of protein) prepared from HEK293- $\alpha 3 \beta 4$ cells and homogenate ( $10 \mu \mathrm{g}$ of protein) from mock-transfected HEK293 cells were solubilized in Laemmli sample buffer, subjected to $10 \%$ SDSPAGE, and transferred onto PVDF membranes (Millipore, USA). The blots were blocked in Tris-buffered saline (TBS) containing 3\% BSA and $0.04 \%$ NP-40 for 1 $\mathrm{hr}$ and sequentially incubated in 1) primary antibody (Table 1) overnight at $4^{\circ} \mathrm{C} ; 2$ ) washing solution (TBS containing $0.04 \%$ NP-40), three changes, each $15 \mathrm{~min}$; 3) horseradish peroxidase (HRP)-conjugated secondary antibodies (Table 1) for $1 \mathrm{hr}$ at RT; and 4) washing solution, three changes, each $15 \mathrm{~min}$. Immunoreactive bands were visualized using ECL Plus Western Blotting Detection Reagents (GE Healthcare Japan, Japan).

\subsection{Assay for Antibody-Induced Internalization of $\alpha 3$ Subunits}

HEK293- $\alpha 3 \beta 4$ cells were seeded at $5.0 \times 10^{4}$ cells $/ \mathrm{cm}^{2}$ on glass coverslips. On the second day, the cells were pre-incubated in Locke's buffer $(154 \mathrm{mM} \mathrm{NaCl}, 5.6 \mathrm{mM}$ $\mathrm{KCl}, 2.3 \mathrm{mM} \mathrm{CaCl}_{2}, 1.0 \mathrm{mM} \mathrm{MgCl}_{2}, 3.6 \mathrm{mM} \mathrm{NaHCO}$, $5 \mathrm{mM}$ glucose and $5 \mathrm{mM}$ HEPES, at $\mathrm{pH} 7.2$ ) for $30 \mathrm{~min}$ at $4{ }^{\circ} \mathrm{C}$ or $37^{\circ} \mathrm{C}$, and then incubated with $1 \mu \mathrm{g} / \mathrm{mL}$ rat anti- $\alpha 3$ subunit antibody (Covance, USA) in the Locke's buffer at $4^{\circ} \mathrm{C}$ or $37^{\circ} \mathrm{C}$. In some cases, Locke's buffer containing $0.45 \mathrm{M}$ sucrose was used as hypertonic condition.

\subsection{Immunofluorescence Staining}

HEK293- $\alpha 3 \beta 4$ and mock-transfected HEK293 cells were fixed in ice-cold 4\% paraformaldehyde (PFA) for $20 \mathrm{~min}$, washed in phosphate-buffered saline (PBS), blocked in PBS containing 1\% BSA and $0.3 \%$ Triton X-100 for 30 min, and incubated with primary antibodies (Table 1) overnight at $4^{\circ} \mathrm{C}$. The cells were washed in PBS containing $0.3 \%$ Triton X-100 (PBS-T), incubated with secondary antibodies (Table 1) for $1 \mathrm{hr}$ at RT, and again washed in PBS-T. For cell-surface staining, Triton X-100 was omitted from all solutions. The coverslips were mounted on glass slides with Dapi-Fluoromount-G (Southern Biotech, USA). Images were captured by a BX51 fluorescence microscope (Olympus, Japan).

\subsection{Cell-Surface Enzyme-Linked Immunosorbent Assay (ELISA)}

$\alpha 3$ subunits expressed on cell-surface membrane were quantitated by cell-surface ELISA. HEK293- $\alpha 3 \beta 4$ cells

Table 1. List of antibodies used in this study.

\begin{tabular}{|c|c|c|c|c|}
\hline Antibody & Species/Clonality & Source (Catalogue No.) & Dilution & Usage \\
\hline \multicolumn{5}{|l|}{ Primary antibody } \\
\hline Anti-nAChR $\alpha 3$ subunit & Rabbit/Polyclonal & Santa Cruz (sc-5590) & $1: 1,000$ & IF, IB \\
\hline Anti-nAChR $\beta 4$ subunit & Rabbit/Polyclonal & Millipore (AB15327) & $1: 2,000$ & IF, IB \\
\hline Anti-EEA1 & Rabbit/Polyclonal & Abcam (ab2900) & $1: 1,000$ & IF \\
\hline \multicolumn{5}{|l|}{ Secondary antibody } \\
\hline Alexa Fluor 488-conjugated anti-rat IgG & Donkey & Invitrogen (A21208) & $1: 2,000$ & IF \\
\hline Alexa Fluor 594-conjugated anti-rabbit IgG & Donkey & Invitrogen (A21207) & $1: 2,000$ & IF \\
\hline HRP-conjugated & anti-rat IgG Rabbit & Abcam (ab7104) & $1: 5,000$ & CSE \\
\hline HRP-conjugated & anti-rabbit IgG Goat & BIO-RAD (170-6515) & $1: 10,000$ & IB \\
\hline
\end{tabular}

IF, immunofluorescence staining; IB, immunoblot analysis; CSE, cell-surface ELISA; HRP, horseradish peroxidase. 

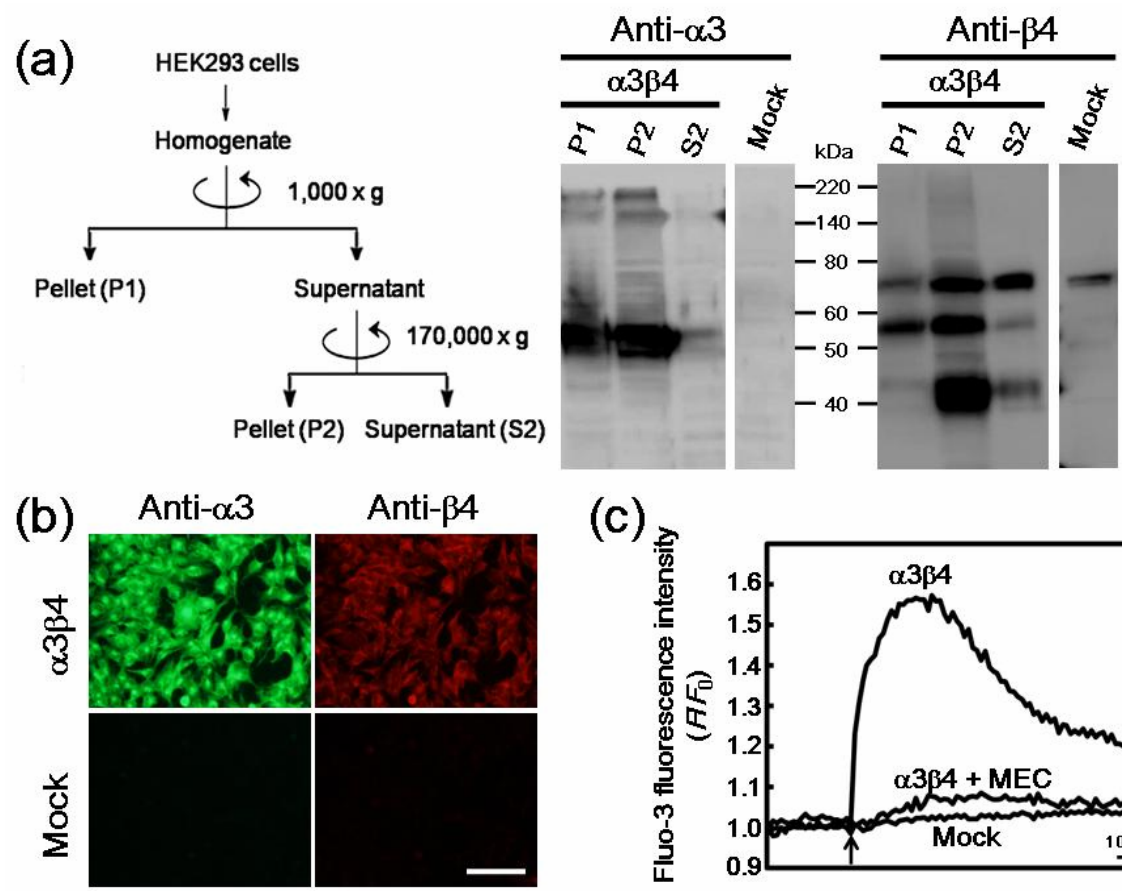

(c)

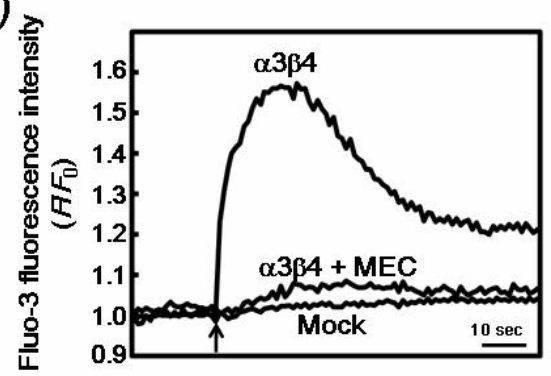

Figure 1. Establishment of human embryonic kidney (HEK) 293 cells stably co-expressing $\alpha 3$ and $\beta 4$ subunits (HEK293- $\alpha 3 \beta 4$ cells). (a) Immunoblot analysis of subcellular fractions (P1, $\mathrm{P} 2$ and $\mathrm{S} 2$, each $10 \mu \mathrm{g}$ of protein) prepared from HEK293- $\alpha 3 \beta 4$ cells $(\alpha 3 \beta 4)$ and homogenates (10 $\mu \mathrm{g}$ of protein) from mock-transfected HEK293 cells (Mock). Subcellular fractionation procedure was described in the left. Blots were probed with rabbit anti- $\alpha 3$ (Anti- $\alpha 3$ ) or rabbit anti- $\beta 4$ (Anti- $\beta 4$ ) subunit antibody. Indicated are molecular weight markers $(\mathrm{kDa})$. (b) Immunofluorescence staining. HEK293- $\alpha 3 \beta 4$ cells $(\alpha 3 \beta 4)$ and mock-transfected HEK293 cells (Mock) were co-stained with rat anti- $\alpha 3$ (Anti- $\alpha 3$ ) and rabbit anti- $\beta 4$ (Anti- $\beta 4$ ) subunit antibodies under non-permeable condition, and detected with Alexa Fluor 488-conjugated anti-rat IgG (green) and Alexa Fluor 594-conjugated anti-rabbit IgG (red) antibodies. Scale bar, 100 $\mu \mathrm{m}$. (c) Intracellular $\mathrm{Ca}^{2+}$ assay. Fluo-3 AM-loaded HEK293- $\alpha 3 \beta 4$ cells $(\alpha 3 \beta 4)$ and mocktransfected HEK293 cells (Mock) were stimulated with $1 \mathrm{mM}$ nicotine (Arrow). $\alpha 3 \beta 4+$ MEC, HEK293- $\alpha 3 \beta 4$ cells were pre-incubated with $1 \mathrm{mM}$ mecamylamine (MEC) for $30 \mathrm{~min}$. Data shown are representative responses from two independent experiments, and expressed as $F / F_{0}$. $F$ is the value of fluorescence intensity; $F_{0}$ is intensity at the time 0 .

were seeded into each well of a 24 -well culture plate at $2.5 \times 10^{5}$ cells $/ \mathrm{cm}^{2}$. On the second day, the cells were incubated with $1 \mu \mathrm{g} / \mathrm{mL}$ rat anti- $\alpha 3$ subunit antibody in isotonic or hypertonic Locke's buffer for $5-30 \mathrm{~min}$ at $37^{\circ} \mathrm{C}$. The cells were washed in Locke's buffer at $4^{\circ} \mathrm{C}$ and $\alpha 3$ subunits on the cell-surface were labeled with 1 $\mu \mathrm{g} / \mathrm{mL}$ rat anti- $\alpha 3$ subunit antibody in the Locke's buffer for $30 \mathrm{~min}$ at $4^{\circ} \mathrm{C}$. The cells were then fixed in ice-cold $4 \%$ PFA for $20 \mathrm{~min}$. After fixation, the cells were washed in PBS and blocked in PBS containing 1\% BSA for 30 min. And then, the cells were incubated with HRP-conjugated anti-rat IgG antibody (Table 1) for $1 \mathrm{hr}$ at RT and washed in PBS. Signals were generated using TMB microwell peroxidase substrate system (KPL, USA). After stopping the reaction with $2 \mathrm{M}$ sulfuric acid, absorbance of the dye was measured at a wavelength of $450 \mathrm{~nm}$ using Multiskan MS-UV (Thermo Fisher Scientific, Finland).

\subsection{Intracellular $\mathrm{Ca}^{2+}$ Assay}

Intracellular $\mathrm{Ca}^{2+}$ levels were measured using Fluo-3 AM, membrane-permeable $\mathrm{Ca}^{2+}$-sensitive fluorescent dye. HEK293- $\alpha 3 \beta 4$ and mock-transfected HEK293 cells were seeded into $35-\mathrm{mm}$ glass bottom dish or each well of a 96-well culture plate at $2.0 \times 10^{5} \mathrm{cells} / \mathrm{cm}^{2}$. On the third day, we incubated the cells in Locke's buffer containing $10 \mu \mathrm{M}$ Fluo-3 AM (Dojindo Laboratories, Japan) for 60 min at $37^{\circ} \mathrm{C}$. The cells were washed in Locke's buffer, and incubated with $1 \mu \mathrm{g} / \mathrm{mL}$ rat anti- $\alpha 3$ subunit antibody or $1 \mathrm{mM}$ mecamylamine (Sigma-Aldrich, USA) in Locke's buffer for $5-30 \mathrm{~min}$ at $4^{\circ} \mathrm{C}$ or $37^{\circ} \mathrm{C}$. Nicotine (Wako Pure Chemical Industries, Japan) was diluted in Locke's buffer and added to the cells at a final concentration of $1 \mathrm{mM}$. Fluorescence images of the cells on the $35-\mathrm{mm}$ glass bottom dish were recorded using BIOREVO BZ-9000 fluorescence microscope (Keyence, 
Japan). Fluorescence intensity of the cells on the 96-well culture plate was measured using a fluorometric plate reader (Fluoroskan Ascent; Thermo Fisher Scientific) at $485 \mathrm{~nm}$ excitation and $538 \mathrm{~nm}$ emission.

\section{RESULTS}

To examine the effects of the antibody on cell-surface $\alpha 3$ subunits in vitro, we used HEK293- $\alpha 3 \beta 4$ cells [8]. The cellular distribution of both subunits was examined by immunoblot analysis using subcellular fractions prepared from HEK293- $\alpha 3 \beta 4$ cells (Figure 1(a)). We used P1, P2 and S2 fractions as nuclear, membrane and cytosolic fractions, respectively. Predicted bands of $\alpha 3(50-\mathrm{kDa})$ and $\beta 4(55-\mathrm{kDa})$ subunits were detected using each specific antibody in all subcellular fractions from HEK293- $\alpha 3 \beta 4$ cells, but not in homogenate from mock-transfected cells. Both subunits were mainly detected in P2 fraction of HEK293- $\alpha 3 \beta 4$ cells. The $42-\mathrm{kDa}$ band recognized by anti- $\beta 4$ subunit antibody might represent a proteolytic form. The $70-\mathrm{kDa}$ band, which was also present in the mock-transfected cells, might be due to non-specific reactions. Immunoreactivities for $\alpha 3$ and $\beta 4$ subunits were detected by immunofluorescence staining under non-permeable condition, indicating sta- ble co-expression on the cell-surface (Figure 1(b)). To confirm whether exogenous $\alpha 3$ and $\beta 4$ subunits formed functional $\mathrm{nAChR}$, we examined nicotine-evoked $\mathrm{Ca}^{2+}$ influx using Fluo-3 AM (Figure 1(c)). Nicotine elicited a transient elevation of fluorescence intensity (1.56-fold) in HEK293- $\alpha 3 \beta 4$ cells, but not in mock-transfected cells ( $<1.1$-fold). Mecamylamine, an antagonist of neuronal nAChRs, inhibited the $\mathrm{Ca}^{2+}$ influx in HEK293- $\alpha 3 \beta 4$ cells (Figure 1(c)). These data indicate the expression of functional nAChRs assembled from $\alpha 3$ and $\beta 4$ subunits on the cell-surface.

Using this cell line, we examined antibody-induced internalization of $\alpha 3$ subunits. After application of rat antibody recognizing extracellular $\mathrm{NH}_{2}$-terminal domain of $\alpha 3$ subunit (Anti- $\alpha 3$ ) for $30 \mathrm{~min}$, internalized antibodies were detected by Alexa Fluor 488-conjugated anti-rat IgG antibody. At the same time, $\alpha 3$ subunits were stained with rabbit antibody against second intracellular loop of $\alpha 3$ subunit, followed by detection with Alexa Fluor 594-conjugated anti-rabbit IgG antibody. When the cells were incubated with Anti- $\alpha 3$ at $37^{\circ} \mathrm{C}$ under isotonic condition, punctate rat IgG-immunoreactivity (IR) overlapped largely with punctate $\alpha 3$ subunit-IR (Figure 2(a)). In contrast, low-temperature and hypertonic condition

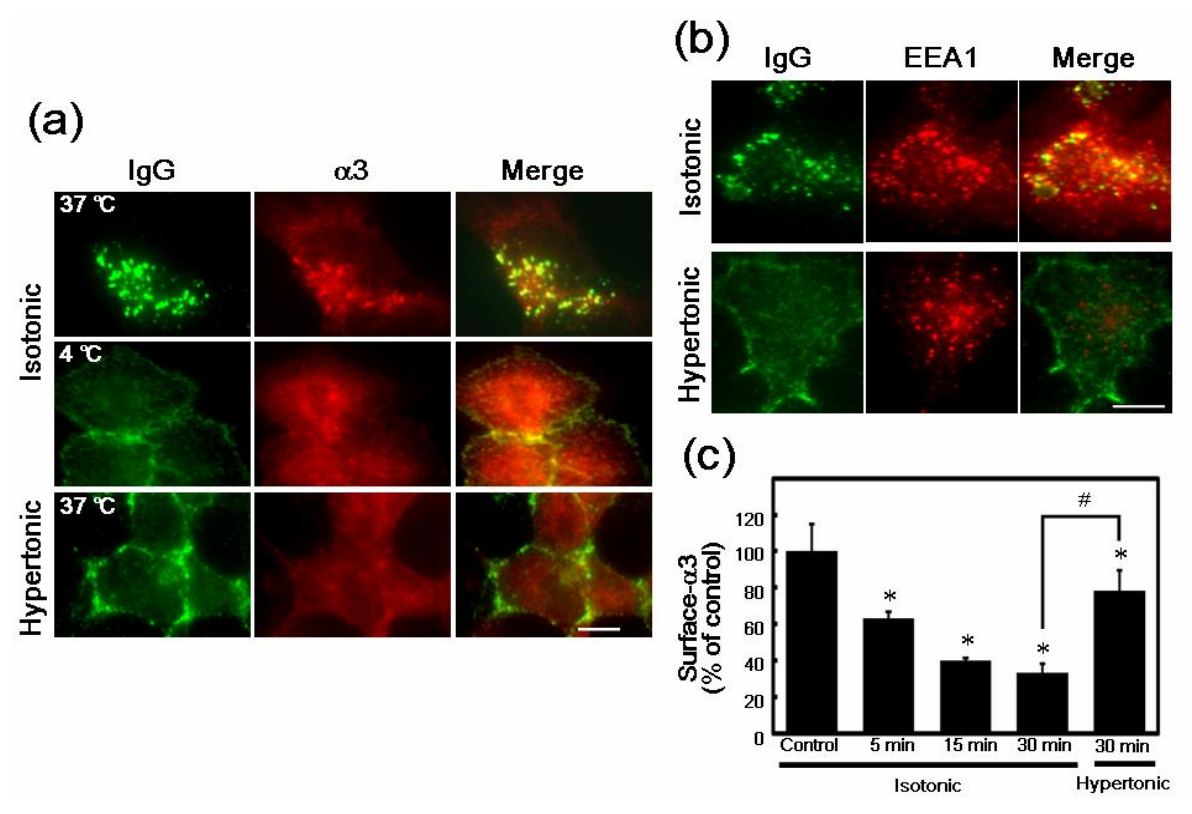

Figure 2. Antibody-induced endocytosis of $\alpha 3$ subunits in HEK293- $\alpha 3 \beta 4$ cells. (a, b) HEK 293- $\alpha 3 \beta 4$ cells were incubated with $1 \mu \mathrm{g} / \mathrm{mL}$ rat anti- $\alpha 3$ subunit antibody for $30 \mathrm{~min}$ at $37^{\circ} \mathrm{C}$ or $4^{\circ} \mathrm{C}$ in isotonic or hypertonic condition. The cells were then fixed, permeabilized and co-stained with rabbit anti- $\alpha 3$ subunit antibody (a) or rabbit anti-EEA1 antibody (b), followed by detection with Alexa Fluor 488-conjugated anti-rat IgG (green) and Alexa Fluor 594-conjugated anti-rabbit IgG (red) antibodies. Scale bars, $5 \mu \mathrm{m}$. (c) Quantification of $\alpha 3$ subunit expressed on the cell-surface membrane by cell-surface ELISA. HEK293- $\alpha 3 \beta 4$ cells were incubated with $1 \mu \mathrm{g} / \mathrm{mL}$ rat anti- $\alpha 3$ subunit antibody in isotonic or hypertonic condition for indicated time periods at $37^{\circ} \mathrm{C}$. Data are expressed as means \pm S.D. from three independent experiments. Statistical comparisons were carried out by one-way ANOVA followed by Tukey test. ${ }^{*} p<0.01$ vs. Control; ${ }^{\#} p<0.01$. 
inhibited the formation of punctate-IR for the rat IgG and $\alpha 3$ subunit. We next examined involvement of endocytic machinery in antibody internalization by double-labeled immunofluorescence staining using anti-early endosome antigen1 (EEA1) antibody (Figure 2(b)). When HEK293$\alpha 3 \beta 4$ cells were incubated with Anti- $\alpha 3$ for $30 \mathrm{~min}$ at $37^{\circ} \mathrm{C}$ in isotonic Locke's buffer, punctate rat IgG-IR were largely overlapped with punctate EEA1-IR. In contrast, no double-positive dots were formed under hypertonic condition. $\alpha 3$ subunits on the cell-surface were quantitated by cell-surface ELISA (Figure 2(c)). Application of Anti- $\alpha 3$ in isotonic Locke's buffer for 5, 15 and $30 \mathrm{~min}$ at $37^{\circ} \mathrm{C}$ resulted in $37 \%, 60 \%$ and $67 \%$ decreases, respectively. Under hypertonic condition, the reduction at 30 min was significantly suppressed $(21 \%, p<0.01)$.

To examine whether the Anti- $\alpha 3$ inhibited nAChR function, we evaluated nicotine-evoked $\mathrm{Ca}^{2+}$ influx using Fluo-3 AM. When HEK293- $\alpha 3 \beta 4$ cells were incubated with Anti- $\alpha 3$ for $30 \mathrm{~min}$, nicotine-evoked elevation of fluorescence intensity was remarkably suppressed compared with the control cells (Figure 3(a)). We analyzed peak Fluo-3 fluorescence intensities obtained by addition of nicotine (Figures 3(b) and (c)). Application of Anti$\alpha 3$ for 5,15 and 30 min resulted in $24 \%, 42 \%$ and $63 \%$ decreases of peak fluorescence intensity, respectively (Figure 3(b)). In contrast, when the cells were incubated with the antibody at $4^{\circ} \mathrm{C}$, no reduction was detected (Figure 3(c)). These results clearly indicate that the reduction in $\mathrm{Ca}^{2+}$ influx is due to decrease of cell-surface nAChRs, and that antagonistic effect of the antibody is little, if any.

\section{DISCUSSION}

In the present study, we showed that the antibody-induced reduction of cell-surface $\alpha 3$ subunits is the main cause of ganglionic nAChR dysfunction. Since these effects of the antibody were markedly inhibited under low-temperature or hypertonic condition, endocytic machinery could impair the fast excitatory synaptic transmission in autonomic ganglia of AAG patients.

The antibody-induced internalization of ganglionic nAChR has been suggested to be involved in the auto-

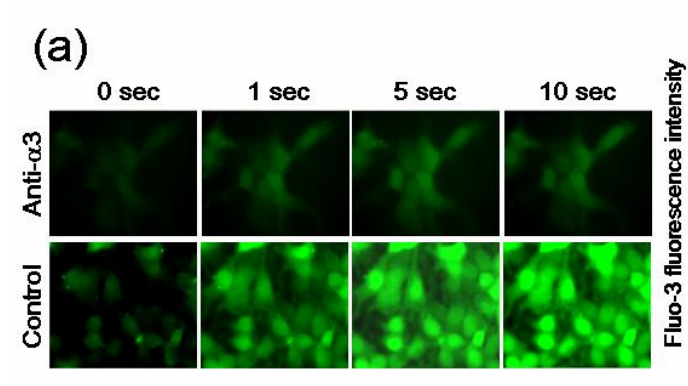

(b)

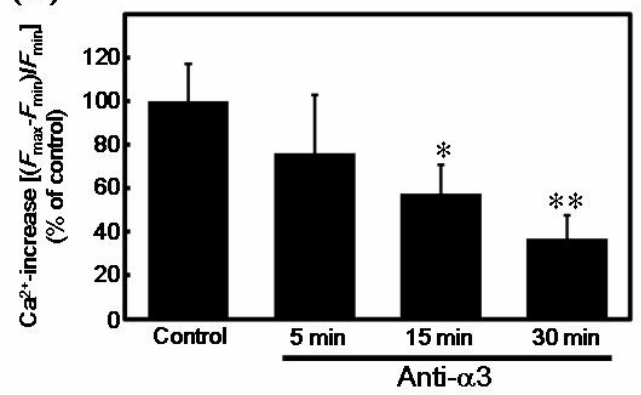

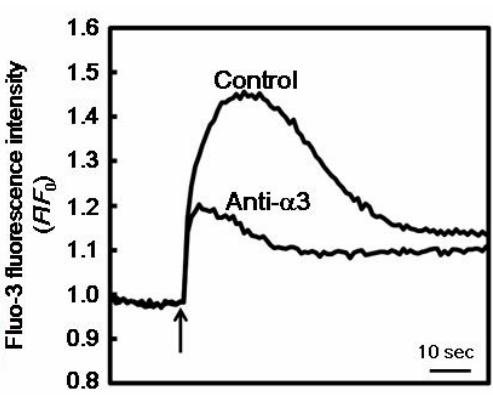

(c)

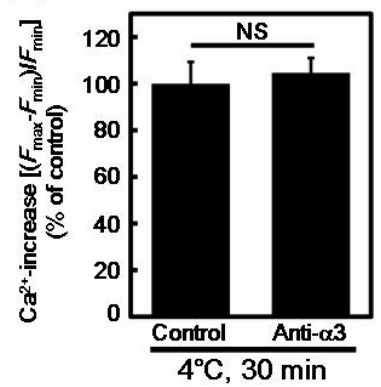

Figure 3. Antibody-induced dysfunction of nAChR. (a) Fluo-3 AM-loaded HEK293- $\alpha 3 \beta 4$ cells were incubated with or without $1 \mu \mathrm{g} / \mathrm{mL}$ rat anti- $\alpha 3$ subunit antibody (Anti- $\alpha 3$ ) for 30 min at $37^{\circ} \mathrm{C}$, and then stimulated by $1 \mathrm{mM}$ nicotine. Changes in intracellular $\mathrm{Ca}^{2+}$ concentration was monitored using a fluorescence microscope (left) and a fluorometric plate reader (right). Addition of nicotine is pointed by arrow. Data shown are representative responses from two independent experiments, and expressed as $F / F_{0}$. (b, c) Peak Fluo-3 fluorescence intensity. The cells were incubated with or without $1 \mu \mathrm{g} / \mathrm{mL}$ rat anti- $\alpha 3$ subunit antibodies (Anti- $\alpha 3$ ) for indicated time periods at $37^{\circ} \mathrm{C}$ (b) or for $30 \mathrm{~min}$ at $4^{\circ} \mathrm{C}$ (c). Data are expressed as means \pm S.D. of $\left[\left(F_{\max }-F_{\min }\right) / F_{\min }\right]$ from three independent experiments. $F_{\max }$ is peak fluorescence intensity; $F_{\min }$ is averaged fluorescence intensity of the first 1 to 20 counts before the addition of nicotine. Statistical comparisons were carried out by one-way ANOVA followed by Dunnett's test or two-tailed $t$-test. ${ }^{*} p<0.05,{ }^{* *} p<0.01$ vs. Control. NS, not significant. 
nomic dysfunction. Interestingly, Wang et al. [9] reported that whole $\operatorname{IgG}$ from seropositive AAG patients decreased the nAChR current in IMR-32 neuroblastoma cells, but Fab fragments did not. In addition, nAChR current was not inhibited by the autoantibodies under low-temperature condition. Although their results suggest that the impairment of the ganglionic $\mathrm{nAChR}$ function requires the antibody-mediated cross-linking and the subsequent internalization of cell-surface $\alpha 3$ subunits, there is no direct experimental evidence. In this study, we demonstrated intracellular punctate accumulation of antibody- $\alpha 3$ subunit complexes and localization of the antibodies in endocytic vesicles. In addition, our results from cell-surface ELISA indicated that antibody-induced reduction in cell-surface $\alpha 3$ subunits was rapidly progressed within $30 \mathrm{~min}$ as predicted by Wang et al. [9]. The antibody simultaneously caused $\mathrm{nAChR}$ dysfunction within 30 min as shown by loss of nicotine-evoked $\mathrm{Ca}^{2+}$ influx. When the endocytic machinery was inhibited by low-temperature or hypertonicity [10], the effects of the antibody described above were remarkably attenuated.

Although it remains to be seen whether these effects of anti- $\alpha 3$ subunit antibody could be induced in vivo, Lennon et al. [5] reported that rabbit injected with $\mathrm{NH}_{2}$-terminal extracellular domain (ECD) of $\alpha 3$ subunit protein exhibited autonomic failure. Furthermore, IgG collected from this animal model produced a progressive decline of nAChR current in IMR-32 neuroblastoma cells [9]. We previously demonstrated in HEK293- $\alpha 3 \beta 4$ cells that the antibody against ECD of $\alpha 3$ subunit induced the internalization and cytoplasmic accumulation of the $\alpha 3$ subunits [8]. Our present study extends these previous observations about pathogenic mechanisms of anti- $\alpha 3$ subunit autoantibody.

In conclusion, this study clearly demonstrates the involvement of endocytic machinery in the antibody-induced reduction in cell-surface $\alpha 3$ subunits and impairment of ganglionic nAChR function. Our data reinforce the idea that reduction of the ganglionic $\mathrm{nAChR}$ in autonomic ganglia plays an important pathogenic role in seropositive AAG patients. Our approaches described in this report may help to clarify the pathogenicity of the individual anti- $\alpha 3$ subunit autoantibody.

\section{ACKNOWLEDGEMENTS}

This work was supported in part by a Health and Labour Sciences Research Grant on Intractable Diseases (Neuroimmunological Diseases) from the Ministry of Health, Labour and Welfare of Japan, and KAKENHI (24591253).

\section{REFERENCES}

[1] McKeon, A., Lennon, V.A., Lachance, D.H., Fealey, R.D. and Pittock, S.J. (2009) Ganglionic acetylcholine receptor autoantibody: Oncological, neurological, and serological accompaniments. Archives of Neurology, 66, 735-741. doi:10.1001/archneurol.2009.78

[2] Vernino, S., Low, P.A., Fealey, R.D., Stewart, J.D., Farrugia, G. and Lennon, V.A. (2000) Autoantibodies to ganglionic acetylcholine receptors in autoimmune autonomic neuropathies. The New England Journal of Medicine, 343, 847-855.

doi:10.1056/NEJM200009213431204

[3] Skok, V.I. (2002) Nicotinic acetylcholine receptors in autonomic ganglia. Autonomic Neuroscience, 97, 1-11. doi:10.1016/S1566-0702(01)00386-1

[4] Albuquerque, E.X., Pereira, E.F., Alkondon, M. and Rogers, S.W. (2009) Mammalian nicotinic acetylcholine receptors: From structure to function. Physiological Reviews, 89, 73-120. doi:10.1152/physrev.00015.2008

[5] Lennon, V.A., Ermilov, L.G., Szurszewski, J.H. and Vernino, S. (2003) Immunization with neuronal nicotinic acetylcholine receptor induces neurological autoimmune disease. The Journal of Clinical Investigation, 111, 907913. doi:10.1172/JCI200317429

[6] Vernino, S., Ermilov, L.G., Sha, L., Szurszewski., J.H., Low, P.A. and Lennon, V.A. (2004) Passive transfer of autoimmune autonomic neuropathy to mice. The Journal of Neuroscience, 24, 7037-7042. doi:10.1523/JNEUROSCI.1485-04.2004

[7] Vernino, S., Lindstrom, J., Hopkins, S., Wang, Z. and Low, P.A. (2008) Characterization of ganglionic acetylcholine receptor autoantibodies. Journal of Neuroimmunology, 197, 63-69. doi:10.1016/j.jneuroim.2008.03.017

[8] Kobayashi, S., Yokoyama, S., Maruta, T., Negami, M., Muroyama, A., Mitsumoto, Y., Iwasa, K., Yamada, M. and Yoshikawa, H. (2013) Autoantibody-induced internalization of nicotinic acetylcholine receptor $\alpha 3$ subunit exogenously expressed in human embryonic kidney cells. Journal of Neuroimmunology, 257, 102-106. doi:10.1016/j.jneuroim.2012.12.010

[9] Wang, Z., Low, P.A., Jordan, J., Freeman, R., Gibbons, C.H., Schroeder, C., Sandroni, P. and Vernino, S. (2007) Autoimmune autonomic ganglionopathy: IgG effects on ganglionic acetylcholine receptor current. Neurology, 68, 1917-1921. doi:10.1212/01.wn1.0000263185.30294.61

[10] Arancibia-Carcamo, I.L., Fairfax, B.P., Moss, S.J. and Kittler, J.T. (2006) Studying the localization, surface stability and endocytosis of neurotransmitter receptors by antibody labeling and biotinylation approaches. The dynamic synapse: Molecular methods in ionotropic receptor biology, Frontiers in Neuroscience. CRC Press, Boca Raton. 